\title{
Biochar compost blends facilitate switchgrass growth in mine soils by reducing $\mathrm{Cd}$ and $\mathrm{Zn}$ bioavailability
}

\author{
Jeffrey M. Novak ${ }^{1}$ ( ) James A. Ippolito ${ }^{2}$ - Donald W. Watts ${ }^{1} \cdot$ Gilbert C. Sigua ${ }^{1} \cdot$ Thomas F. Ducey $^{1} \cdot$ Mark G. Johnson $^{3}$
}

Received: 31 January 2019 / Accepted: 2 March 2019 / Published online: 29 March 2019

(c) The Author(s) 2019

\begin{abstract}
Biochars have the potential to reclaim mine-impacted soils; however, their variable physico-chemical properties incite speculation about their successful remediation performance. This investigation examined the capability of biochars produced from three different feedstocks along with a compost blend to improve switchgrass growth conditions in a mine-impacted soil by examining influences on soil $\mathrm{pH}$, grass metal contents, and soil-extractable metal concentrations. Cadmium (Cd)- and zinc (Zn)-contaminated mine soil was collected from a site near Webb City, Missouri, USA - a location within the Tri-State Mining District. In a full factorial design, soil was treated with a $0 \%, 2.5 \%$, and $5 \%(w / w)$ compost mixture (wood chips + beef cattle manure), and $0 \%, 2.5 \%$ and $5 \%$ of each biochar pyrolyzed from beef cattle manure, poultry litter, and lodgepole pine feedstocks. Switchgrass (Panicum virgatum, 'Cave-In-Rock' variety) was grown in a greenhouse for 50 days and the mass of shoots (above-ground biomass) and roots was assessed, while soil $\mathrm{pH}$, deionized $\mathrm{H}_{2} \mathrm{O}$ - and $0.01 \mathrm{M} \mathrm{CaCl}_{2}$-extractable $\mathrm{Cd}$ and $\mathrm{Zn}$ concentrations were measured. Poultry litter biochar and compost had the greatest ability to raise soil $\mathrm{pH}$ (from 4.40 to 6.61), beef cattle manure biochar and compost moderately raised $\mathrm{pH}$ (from 4.4 to 5.92), and lodgepole pine biochar and compost weakly raised $\mathrm{pH}$ (from 4.40 to 5.05). Soils treated with beef cattle manure biochar, poultry litter biochar significantly reduced deionized $\mathrm{H}_{2} \mathrm{O}$ - and $0.01 \mathrm{M} \mathrm{CaCl}_{2}$-extractable $\mathrm{Cd}$ and $\mathrm{Zn}$ concentrations, while lodgepole pine biochar-treated soils showed mixed results. Switchgrass shoot and root masses were greatest in soil treated with compost in combination with either beef cattle manure biochar or poultry litter biochar. Soils treated with $5 \%$ beef cattle manure biochar $+5 \%$ compost had greater reductions in total $\mathrm{Cd}$ and $\mathrm{Zn}$ concentrations measured in switchgrass shoots and roots compared to the other two treatments. The three biochars and compost mixtures applied to heavy metal, mine-impacted soil had considerable performance dissimilarities for improving switchgrass productivity. Switchgrass growth was noticeably improved after treatment with the compost in combination with biochar from beef cattle manure or poultry litter. This may be explained by the increased soil $\mathrm{pH}$ that promoted $\mathrm{Zn}$ and $\mathrm{Cd}$ precipitation and organic functional groups that reduced soil-available heavy metal concentrations. Our results imply that creating designer biochars is an important management component in developing successful mine-site phytostabilization programs.
\end{abstract}

Keywords Biochar $\cdot$ Heavy metals $\cdot$ Metal sorption $\cdot$ Tri-State Mine soil $\cdot$ Remediation $\cdot$ Switchgrass

Electronic supplementary material The online version of this article (https://doi.org/10.1007/s42773-019-00004-7) contains supplementary material, which is available to authorized users.

Jeffrey M. Novak

jeff.novak@ars.usda.gov

1 Coastal Plains Soil, Water and Plant Research Center, United States Department of Agriculture, Agricultural Research Service, Florence, SC 29501, USA

2 Department of Soil and Crop Sciences, Colorado State University, Fort Collins, CO 80523, USA

3 National Health and Environmental Effects Research Laboratory, United States Environmental Protection Agency, Corvallis, OR 97331, USA

\section{Introduction}

Mining activities and ensuing disposal of waste products can have profound impacts on soil health characteristics (low $\mathrm{pH}$, toxic heavy metals concentrations, etc.) where mine wastes are stored. Reports have revealed that milling operations, rock grinding, concentrating ores processes, and disposal of sulfurous tailings can lower soil pH (Dudka and Adriano 1997; Novak et al. 2018), create poor microbial habitat conditions (Cui et al. 2013; Hu et al. 2014), reduce soil microbial enzyme activity (Hanauer et al. 2012; Nie et al. 2018; Novak et al. 2018), and contribute to toxic metal 
concentrations in soils (Kabata-Pendias 2001; Schreurs et al. 2011). Stabilizing mine tailings and mine-impacted soils with a ground cover is an important management practice because plants can minimize off-site movement of toxic metals and can add organic matter to improve soil chemical characteristics for better plant growth (Brown et al. 2003b; Figueroa et al. 2010; Maiti and Maiti 2014). Without treatment, however, these poor soil: plant growth characteristics are known to impair ground cover establishment and hence influence the degree of site phytostabilization (Phillips et al. 2016; Rizwan et al. 2016; Kumar et al. 2018). Thus, in mine soil remediation, a key goal is to reduce heavy-metal bioavailability while also improving soil health characteristics (i.e., $\mathrm{pH}$, nutrient availability, etc.) that are conducive for plant growth. To achieve this remediation goal, various materials are often utilized as amendments.

An assortment of conventional materials has been previously employed on mine spoils or mine-impacted soils to modify soil chemical issues and enhance phytostabilization. They include, additions of C-based materials to bolster soil organic matter levels (Norland 1993); adding lime to raise $\mathrm{pH}$ (Hensley and Carpenter 1984; Srivastava and Chhonkur 2000); adding municipal biosolids (Haering et al. 2000; Brown et al. 2003a; Waqas et al. 2014); or introducing wood pulp sludge and/or fly ash ( $\mathrm{Li}$ and Daniels 1997; Gorman et al. 2000; Abbot et al. 2001) to bind metals. Most of these amendments are effective at ameliorating soil: plant chemical issues including raising $\mathrm{pH}$ and sorbing toxic metals. Novak et al. (2018) raised concern, however, that these conventional amendments were not long lasting, required high application rates, and/or could produce malodor issues.

In place of these amendments and their noted shortcomings, current literature adjudicates the use of biochar as an amendment in mine reclamation sites (Ippolito et al. 2017; Kumar et al. 2018; O'Connor et al. 2018). Biochar is now the in-vogue amendment for mine-site restoration because previous research has shown that biochars can bind with heavy metals (Ehsan et al. 2014; Ippolito et al. 2017) as well as improve soil health characteristics by acting as a liming agent (Yuan and Xu 2011; Jian et al. 2014), rebuilding organic matter levels (Brockhoff et al. 2010; Anawar et al. 2015), supplying plant nutrients (Novak et al. 2009; Ippolito et al. 2015; Ahmad et al. 2018) and stimulating soil microbial activity (Ducey et al. 2013). The ability of biochars to reduce bioavailable forms of toxic soil metals is attributed to various immobilization mechanisms, including adsorption, precipitation, and complexation reactions (Rizwan et al. 2016; Ippolito et al. 2017; Wang et al. 2018).

Biochar is a material produced by pyrolysis of organic feedstocks under anoxic conditions using temperatures ranging from 350 to $900{ }^{\circ} \mathrm{C}$ (Laird et al. 2009; Boateng et al. 2015). A variety of feedstocks is available for biochar production including agricultural by-products (i.e., nut shells, peach pits, etc.), forestry residues, wood wastes, crop residues, animal manures, and municipal biosolids (Cantrell et al. 2012; Spokas et al. 2012; Zheng et al. 2013). Reports have shown that the variety of feedstocks, pyrolysis conditions, and biochar supply chain management options contributes to diversity in their chemical and physical properties (Novak et al. 2013; Liu et al. 2015; Anderson et al. 2016). Other investigations corroborate that biochars can have differences in their $\mathrm{pH}$, ash contents, $\mathrm{C} / \mathrm{N}, \mathrm{O} / \mathrm{C}$, and $\mathrm{H} / \mathrm{C}$ ratios, porosity, specific surface area, cation exchange capacity, surface charge, $\mathrm{OH}$ - and $\mathrm{COOH}$-containing functional groups, and aromatic $\mathrm{C}-\mathrm{C}$ double bonds that will influence their propensity to react with toxic metals and improve soil chemical conditions (Guo et al. 2015; Sizmur et al. 2015; Xie et al. 2015).

The inherent variability in biochars chemical and structural properties along with diverse characteristics of metalcontaminant characteristics (i.e., valency, $K_{\mathrm{sp}}$, etc.), calls attention to potential performance differences in mine-site remediation ventures (Fellet et al 2011; Kelly et al. 2014). Moreover, poor-performing biochar applied to mine spoils for remediation purposes cannot be physically removed nor economically substituted with another biochar. Thus, it is prudent to perform detailed studies to pre-select a biochar that has a high level of certainty of achieving the desired site remediation results while not negatively impacting soil health characteristics nor facilitating off-site movement of toxic metals.

Therefore, it was our intention to improve the knowledge pool of how biochars produced from diverse feedstocks (poultry litter, lodgepole pine, beef cattle manure) would influence switchgrass (Panicum virgatum) shoot and root growth, metal uptake, while also improving common soil health characteristics $(\mathrm{pH}$, reducing toxic heavy metal bioavailability) in a mine-impacted soil. Along with these biochars, a compost mixture (beef cattle manure + wood chips) was also supplemented with the biochars to potentially stimulate soil microbial activity and enzyme production, which are indicators of soil health status (Cardoso et al. 2013). Mine-impacted soil was obtained from a EPA superfund site known to contain high concentrations of $\mathrm{Cd}$ and $\mathrm{Zn}$ (Johnson et al. 2016). Our hypothesis was that these three biochars would have distinct, but contrary, performance abilities at site remediation to facilitate switchgrass growth and bioavailability of $\mathrm{Cd}$ and $\mathrm{Zn}$ concentrations. Ultimately, these data will be utilized for actual on-site remediation. 


\section{Material and methods}

\subsection{Site, soil description, preparation, and characterization}

A metal-contaminated field was selected near Webb City in Jasper County, Missouri, USA (latitude 37.129272, longitude - 94.447939). This location is part of the Oronogo-Duenweg mining area of the Tri-State Mining District located in Southwest Missouri. Mining of lead $(\mathrm{Pb})$ and zinc $(\mathrm{Zn})$ ore has occurred across this portion of the District with the mining field encompassing approximately 49,800 ha (Johnson et al. 2016). The mine waste ores and tailings were stored in chat piles near production centers (Gibson 1972). The chat piles contain residual $\mathrm{Pb}, \mathrm{Cd}$, and $\mathrm{Zn}$ concentrations, which in some locations leached into the underlying soil or were carried away as dust by winds (EPA 2018).

Potential exposure of $\mathrm{Pb}$ - and $\mathrm{Zn}$-contaminated chat raises human health concerns, so it was prudent to excavate and remove the chat (Johnson et al. 2016). During chat and contaminated soil removal, subsoil was exposed at the surface (Fig. S1). The subsoil was composed of a heterogeneous texture consisting of extremely gravelly silt loam, cobbly clays, which were integrated with cherty-tolimestone rock fragments ranging in size from 2 to $15-\mathrm{cm}$ in diameter (Fig. S1; Soil Survey of Jasper County, Missouri, 2002). The exposed subsoil was leveled across the field with the intent of re-seeding with native grasses. For our purposes, a backhoe was used to collect a few hundred $\mathrm{kg}$ of B/C sub horizon material (See Fig. S1). The subsoil was placed in plastic-lined metal drums and transported to the US Department of Agriculture-Agricultural Research Service-Florence, South Carolina, USA location (USDA-ARS-Florence).

Once in Florence, the subsoil material was air-dried, and screened using a $12.7-\mathrm{cm}$ diameter sieve to collect soil material more appropriate for use in a greenhouse pot experiment. Sieving the soil revealed that it contained approximately $30 \%(\mathrm{w} / \mathrm{w})$ coarse fragments that were $>12.7-\mathrm{cm}$ in diameter. Air-dried soil that passed through the sieve was stored in plastic-lined drums for characterization and for future use in the greenhouse experiment.

The sieved soil was characterized for $\mathrm{pH}$ using a 1:2 (w/w) soil-to-deionized water ratio. Additionally, metal concentrations were extracted using deionized water, bioavailable metals were extracted using $0.01 \mathrm{M} \mathrm{CaCl}_{2}$ (Ippolito et al. 2017), and total metal concentrations were estimated after digestion with $4 \mathrm{M} \mathrm{HNO}_{3}$ (Bradford et al. 1975). Both deionized water and $0.01 \mathrm{M} \mathrm{CaCl}_{2}$ metal concentrations were determined in triplicate by extracting $30 \mathrm{~g}$ soil with
$60 \mathrm{~mL}$ of extractant, shaken for $30 \mathrm{~min}$, and filtered using a nylon $0.45 \mu \mathrm{M}$ filter syringe. Total metal concentrations were determined in triplicate by digestion of $10 \mathrm{~g}$ soil in $100 \mathrm{~mL}$ of $4 \mathrm{M} \mathrm{HNO}_{3}$. All metal concentrations were quantified via inductively coupled plasma-optical emission spectroscopy (ICP-OES) and the data are presented in Table S1.

\subsection{Amendment collection, preparation, pyrolysis, and characterization}

Three feedstocks were used to produce biochars in this experiment. Raw beef cattle manure from a local feedlot operation near Webb City, Missouri, USA was collected from a stockpile (latitude 37.14522, longitude - 94.45206). The manure was mixed with local wood chips (50:50 mixture, $w / w)$ and the blend was exposed to the environment for 2-3 years to allow for conversion into a more degraded manure/compost mixture (George King, personal communication, 2015). A few $\mathrm{kg}$ of the manure compost was transported to the USDA-ARS-Florence location and passed through a 6-mm sieve. The 6-mm sieved beef cattle manure compost was split into two portions - one portion was pyrolyzed at $500{ }^{\circ} \mathrm{C}$ into biochar as outlined (Novak et al. 2014) and the remaining portion was stored for later use in the greenhouse experiment (Sect. 2.3). The remaining two biochars were available commercially and consisted of biochar produced from poultry litter and lodgepole pine feedstocks. The lodgepole pine biochar was produced using a two-stage process as described by Ippolito et al. (2017). Briefly, in the first stage, the feedstock was initially held between 500 and $700{ }^{\circ} \mathrm{C}$ for $<1$ min under a very low $\mathrm{O}_{2}$ atmosphere. In the second stage, the material was pyrolyzed between 300 and $550{ }^{\circ} \mathrm{C}$ for approximately 15 min hold time in an anaerobic environment. After pyrolysis, the lodgepole pine biochar was cooled, and then passed through a $0.25-\mathrm{mm}$ sieve. The poultry litter biochar was produced by gasification using a fixed-bed pyrolyzed programed for conditions (temperature and hold time) that are propriety.

All three biochars and the compost were characterized for their $\mathrm{pH}$ in a 1:2 (w/w) biochar or compost-to-deionized water ratio (Novak et al. 2014). All three biochars were also characterized by ultimate analysis (ASTM D 3176; Hazen Research, Inc., Golden, Colorado, USA) for their ash, C, H, $\mathrm{O}, \mathrm{N}$ and $\mathrm{S}$ contents. Their molar $\mathrm{H} / \mathrm{C}$ and $\mathrm{O} / \mathrm{C}$ ratios were calculated from the elemental analysis (Table S2). Total elemental composition of the ash fraction in the three biochar feedstocks and the manure compost was determined by first ashing the samples at $600{ }^{\circ} \mathrm{C}$, digesting the ash using method SW866 (ASTM 2006), and then quantifying metal content using ICP-OES by Hazen Research, Inc. The chlorine and silica contents in the ash fraction of these four materials were determined using methods ASTM D 2361 and ASTM D 5865, respectively (ASTM 2006). Elemental 
compositional analysis in the ash fraction is reported in Table S2.

\subsection{Greenhouse experiment}

In a factorial design, the treatments for the switchgrass greenhouse experiment consisted of mine soil mixed with biochar at $0 \%, 2.5 \%$, and $5 \%$, and then blended with compost at $0 \%, 2.5 \%$, and $5 \%(\mathrm{w} / \mathrm{w}$; Table S3). Compost produced from beef cattle manure and wood chips was included as a $\mathrm{C}$ source to stimulate microbial activity. Materials were added to $1500 \mathrm{~g}$ of air-dried, $12.7-\mathrm{mm}$ sieved mine soil. After fully hand incorporating the amendments, sufficient deionized water was added to bring the soil gravimetric moisture content to $15 \%(\mathrm{w} / \mathrm{w})$ on an air-dry basis. Preliminary experiments showed that at greater water contents (>15\%), homogeneous dispersing of the amendments into the mine soil was difficult due to clumping.

The treated and untreated mine soils were placed into triplicate plastic pots $(15-\mathrm{cm}$ top diameter $\times 17-\mathrm{cm}$ deep) and gently tapped to a bulk density of $1.5 \mathrm{~g} / \mathrm{cm}^{3}$ as outlined by Novak et al. (2018). About 40 switchgrass seeds were then planted in each pot to a 1-cm depth. The pots were transported to a greenhouse and randomly placed on benches.

The pots remained in the greenhouse for 50 days under a mean air temperature of $29.1^{\circ} \mathrm{C}$ (SD 3.3) and mean relative humidity of $81 \%$ (SD 9.4). On day 16, all pots were fertilized with a $30 \mathrm{~mL}$ solution of $\mathrm{NH}_{4} \mathrm{NO}_{3}$ that delivered an equivalent of $3 \mathrm{~kg} \mathrm{~N} / \mathrm{ha}$ because some treatments exhibited a $\mathrm{N}$-deficient (i.e., chlorosis) symptom. No inorganic $\mathrm{P}$ or $\mathrm{K}$ was added to the pots because these nutrients were supplied with the amendments (Table S2). The pots were irrigated by hand using tap water several times per week over the 50-d experiment.

At termination (day 50), stems and roots were harvested from each pot and oven-dried $\left(60{ }^{\circ} \mathrm{C}\right)$. Plant samples were then digested in a hot block acid digestor using concentrated $\mathrm{HNO}_{3}$ at $60{ }^{\circ} \mathrm{C}$ for $30 \mathrm{~min}$ followed by more digestion at $90{ }^{\circ} \mathrm{C}$ for $90 \mathrm{~min}$ with the addition of $30 \% \mathrm{H}_{2} \mathrm{O}_{2}$ as described by Huang and Schulte (1985). The total $\mathrm{Cd}$ and $\mathrm{Zn}$ concentrations in the digested switchgrass shoots and roots were quantified using ICP-OES. The remaining soils in the pots were oven-dried $\left(105{ }^{\circ} \mathrm{C}\right)$ and then subsamples extracted using deionized $\mathrm{H}_{2} \mathrm{O}, 0.01 \mathrm{M} \mathrm{CaCl}_{2}$, and extractable $\mathrm{Cd}$ and $\mathrm{Zn}$ in each extract was quantified using ICP-OES.

\subsection{Statistics}

Biochar and compost were the fixed factors, while the mean switchgrass shoot and root masses, total $\mathrm{Cd}$ and $\mathrm{Zn}$ concentrations in roots and stems along with soil $\mathrm{pH}$, deionized water, $0.01 \mathrm{M} \mathrm{CaCl}_{2}$ extractable $\mathrm{Cd}$ and $\mathrm{Zn}$ concentrations were the dependent variables in the statistical analysis employing a two-way ANOVA with significance determined at a $P<0.05$. All statistics were completed using Sigma Stat v. 3.5 software (SSPS Corp., Chicago, IL, USA).

\section{Results and discussion}

\subsection{Mine soil and biochar characteristics}

Copper and $\mathrm{Zn}$ are common constituents in the soils' inorganic mineral composition. The $\mathrm{Cu}$ and $\mathrm{Zn}$ concentration in loamy-to-clay-textured soils of the USA can range from 7 to 70 and 20 to $220 \mathrm{mg} / \mathrm{kg}$, respectively (Kabata-Pendias 2001). With respect to Cd, its contents in loamy and claytextured soils in the USA can range from 0.13 to $0.55 \mathrm{mg} /$ kg (Kabata-Pendias 2001). In heavily Cd-contaminated soils, Riley et al. (1992) reported that concentrations can be as high as $345 \mathrm{mg} / \mathrm{kg}$. Cd in soils is regarded as a toxic compound to plants and humans (Wauana and Okieimen 2011). Here, soil material collected at the mine site had a $\mathrm{pH}$ of 4.4 and contained elevated concentrations of total $\mathrm{Cu}, \mathrm{Cd}$, and $\mathrm{Zn}(66.5,72.2$ and $2225 \mathrm{mg} / \mathrm{kg}$, respectively; Table S1). On a positive soil fertility note, this soil contains sufficient total concentrations of important plant nutrients such as K, $\mathrm{Mg}$, and $\mathrm{P}$.

Examining the total, water, and bioavailable concentrations of $\mathrm{Cu}, \mathrm{Cd}$, and $\mathrm{Zn}$ revealed interesting variance between metal availability and binding sites. For example, water and bioavailable $\mathrm{Cu}$ concentrations were $<2.2 \mathrm{mg} / \mathrm{kg}$, implying most of soil $\mathrm{Cu}$ is bound to phases that are not easily removable/bioavailable. In contrast, there were much larger water and bioavailable $\mathrm{Zn}$ and $\mathrm{Cd}$ concentrations compared to $\mathrm{Cu}$. These $\mathrm{Cd}$ and $\mathrm{Zn}$ fractions were probably bound to easily soluble salts and as exchangeable phases on solids (e.g., clays) and organic materials (Beesley and Marmiroli 2011). On a positive note, there was $<0.5 \mathrm{mg} / \mathrm{kg}$ of other water soluble and bioavailable metals such as $\mathrm{Cr}, \mathrm{Ni}$, and $\mathrm{Pb}$ concentrations in this soil (Table $\mathrm{S} 1$ ).

Biochar and compost made from beef cattle manure had relatively medium-high $\mathrm{pH}$ values (6.8 and 9.5 , respectively), but were strikingly low in C content (Table S2). The $\mathrm{C}$ content was low in this feedstock due to exposure to weathering conditions and microbial mineralization during the long-term ( $2-3$ years) composting process. With the loss of $\mathrm{C}$, it should be expected that the ash contents of a manurebased compost would be relatively high $(68.4 \%-83.1 \%$, Table S2; Cantrell et al. 2012). Moreover, their ash is

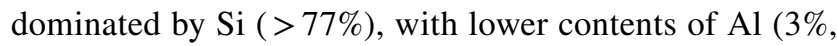
Table S2). These inorganic chemical characteristics imply that soil was included during beef cattle manure feedstock collection from the cattle yard. Others have shown that it is 
not unusual for biochars produced from animal manure feedstocks to contain high ash contents $(50 \%$ to $>70 \%$, Enders et al. 2012; Gunamantha and Widana, 2018).

Biochar produced from lodgepole pine and poultry litter feedstocks both had alkaline $\mathrm{pH}$ values $(\mathrm{pH}>9$, Table $\mathrm{S} 2$ ) which is typical for these two feedstocks (Novak et al. 2013; Ippolito et al. 2015). The $\mathrm{C}$ content was also much higher for lodgepole pine biochar compared to poultry litter biochar, but poultry litter biochar is enriched with plant nutrients such as N, P, and K. Striking results were also noted for the ash compositional differences between these two feedstocks ( $3.2 \%$ vs. $42.5 \%$, Table S2). The plant nutrient compositional differences are consistent with other compositional results in biochar produced from lodgepole pine (Robertson et al. 2012) and poultry litter feedstock (Cantrell et al. 2012; Wang et al. 2015).

\subsection{Soil characteristics after biochar treatment}

Soil $\mathrm{pH}$ increases are important to achieve in acidic mine soil remediation because metal solubility is reduced under alkaline conditions (Bohn et al. 1979; Kabata-Pendias, 2001). Our results corroborate this fact, after measuring the extractability of $\mathrm{Cd}$ and $\mathrm{Zn}$ concentrations in all (Fig. 1a, b). Addition of poultry litter and compost increased soil $\mathrm{pH}$, which concomitantly reduced $\mathrm{H}_{2} \mathrm{O}$ extractable $\mathrm{Cd}$ and $\mathrm{Zn}$ concentrations (Table 1). Moderate reductions in $\mathrm{H}_{2} \mathrm{O}$-extractable $\mathrm{Cd}$ and $\mathrm{Zn}$ were obtained using beef cattle manure and compost (Fig. 1a, b and Table 1) followed by minimal reductions after addition of lodgepole pine biochar and in controls without compost. We suspect that the lodgepole pine biochar did not impact soil $\mathrm{pH}$ to the same degree as the other two biochars as noted in Fig. 1a, b. In soils treated with lodgepole pine biochar and \pm compost, the $\mathrm{pH}$ values were $<5.5$ resulting in more soluble forms of $\mathrm{Cd}$ and $\mathrm{Zn}$ available for extraction. It can also be speculated that the poultry litter biochar was more effective at binding $\mathrm{H}_{2} \mathrm{O}$ soluble $\mathrm{Cd}$ and $\mathrm{Zn}$ because of the presence of ligand sites on the numerous $\mathrm{C}$-assemblies of structures (Guo et al. 2009) and sorption by its mineral ash constituents (Ahmad et al. 2014).

In Fig. 1a, b, three $\mathrm{H}_{2} \mathrm{O}$-extractable $\mathrm{Cd}$ and $\mathrm{Zn}$ outliers occurred in soils treated with $2.5 \%$ poultry litter biochar and $0 \%$ compost, suggesting that compost is necessary to further reduce these two metal concentrations. Without biochar or compost additions, the soil $\mathrm{pH}$ values remain acidic $(\mathrm{pH}<5)$ resulting in higher $\mathrm{H}_{2} \mathrm{O}$-extractable $\mathrm{Cd}(2.5-3.1 \mathrm{mg} / \mathrm{kg})$ and $\mathrm{Zn}$ (75-95 mg/kg, Fig. 1). Among the three biochar amendments, application of poultry litter and compost resulted in the largest increase in mine soil pH (from 4.40 to 6.61; Table 2). Beef cattle manure biochar plus compost showed a moderate soil $\mathrm{pH}$ change from 4.40 to 5.92 , while lodgepole pine biochar additions produced the lowest change
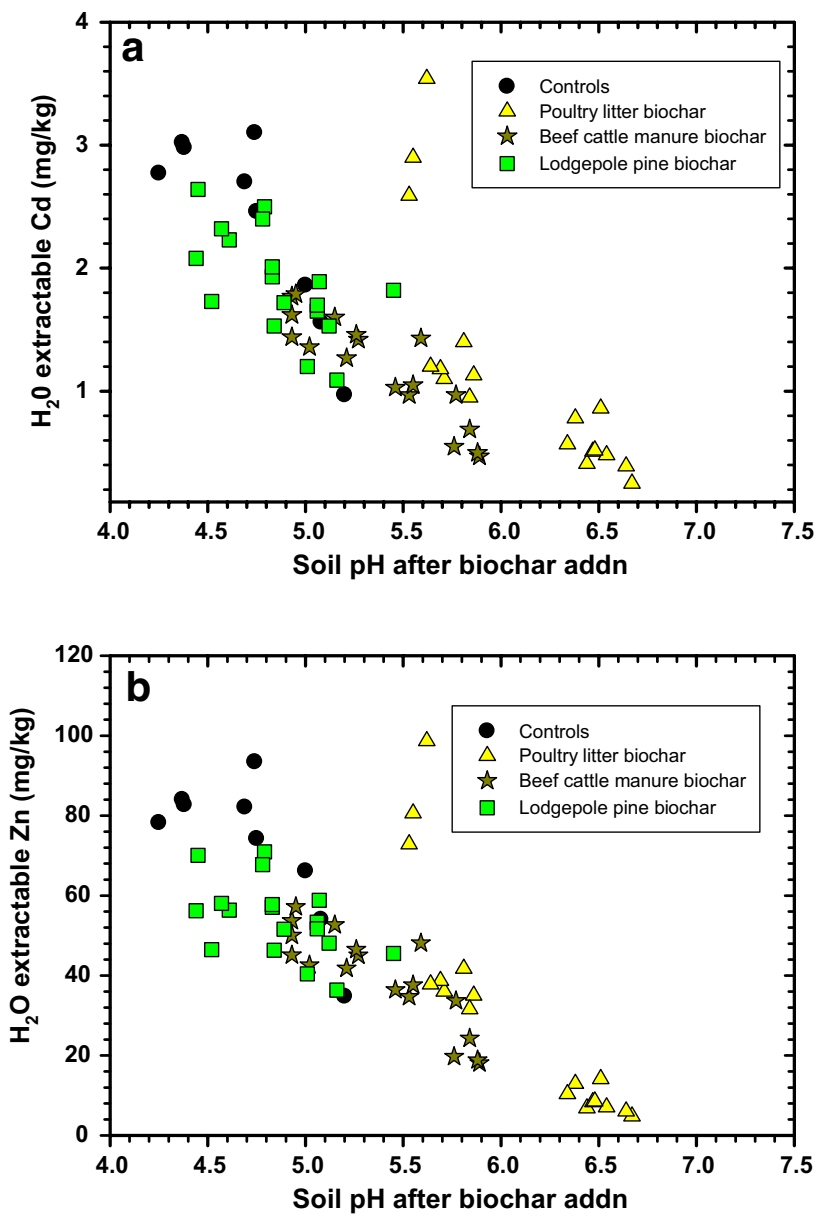

Fig. 1 Water-extractable cadmium $(\mathrm{Cd}, \mathbf{a})$ and zinc $(\mathrm{Zn}, \mathbf{b})$ from compost + biochar-treated Tri-State Mine soil versus their $\mathrm{pH}$ measured at end of study

from 4.40 to 4.81 . Statistical analysis revealed that significant $\mathrm{pH}$ modifications occurred after biochar and compost addition and their interactions were significant (Table 2). However, an additional finding was revealed when choosing organic amendments in mine soils/spoils remediationthe amendments should have a significant liming capacity. Thus, organic amendments should be able to raise spoil/ soil $\mathrm{pH}$ levels to be $>5$ to reduce water-soluble $\mathrm{Cd}$ and $\mathrm{Zn}$ concentrations.

Metals in soils are also extracted using dilute salt solutions such as $0.01 \mathrm{M} \mathrm{CaCl}_{2}$ (salt) that by convention represents the bioavailable fraction (Kim et al. 2015; Ippolito et al. 2017). The bioavailable fraction implies that these metals are plant-available and that they are easily exchangeable with metals held electrostatically on charged surfaces, other salts, and organic ligands. The largest reduction in bioavailable $\mathrm{Cd}$ and $\mathrm{Zn}$ occurred with addition of $5 \%$ poultry litter biochar and compost, with mean concentrations being significantly reduced from 20.2 to $1.4 \mathrm{mg} / \mathrm{kg}$ for $\mathrm{Cd}$, and 


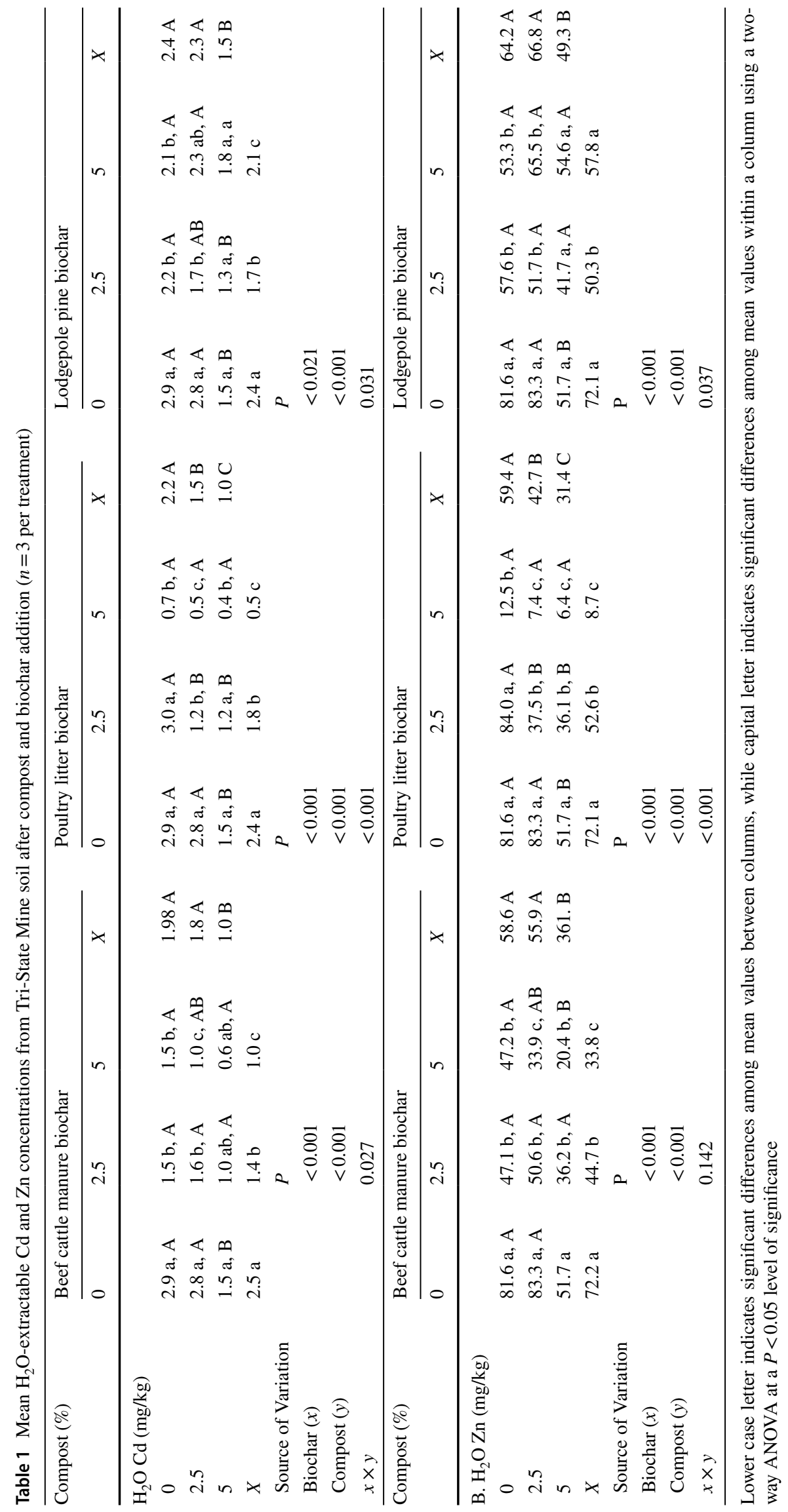


Table 2 Mean $\mathrm{pH}$ of Tri-State Mine soil after compost and biochar addition ( $n=3$ per treatment)

\begin{tabular}{|c|c|c|c|c|c|c|c|c|c|c|c|c|}
\hline \multirow[t]{2}{*}{ Compost $(\%)$} & \multicolumn{4}{|c|}{ Beef cattle manure biochar } & \multicolumn{4}{|c|}{ Poultry litter biochar } & \multicolumn{4}{|c|}{ Lodgepole pine biochar } \\
\hline & 0 & 2.5 & 5 & $X$ & 0 & 2.5 & 5 & $X$ & 0 & 2.5 & 5 & $X$ \\
\hline 0 & $4.40 \mathrm{a}, \mathrm{A}$ & $5.07 \mathrm{~b}, \mathrm{~A}$ & $5.31 \mathrm{c}, \mathrm{A}$ & $4.93 \mathrm{~A}$ & $4.40 \mathrm{a}, \mathrm{A}$ & $5.46 \mathrm{~b}, \mathrm{~A}$ & $6.33 \mathrm{c}, \mathrm{A}$ & $5.39 \mathrm{~A}$ & $4.40 \mathrm{a}, \mathrm{A}$ & $4.37 \mathrm{a}, \mathrm{A}$ & $4.77 \mathrm{a}, \mathrm{A}$ & $4.42 \mathrm{~A}$ \\
\hline 2.5 & $4.69 \mathrm{a}, \mathrm{B}$ & $5.19 \mathrm{~b}, \mathrm{~A}$ & $5.61 \mathrm{c}, \mathrm{B}$ & $5.16 \mathrm{~B}$ & $4.69 \mathrm{a}, \mathrm{B}$ & $5.58 \mathrm{~b}, \mathrm{~A}$ & $6.53 \mathrm{c}, \mathrm{A}$ & $5.60 \mathrm{~B}$ & $4.69 \mathrm{a}, \mathrm{B}$ & $4.77 \mathrm{a}, \mathrm{B}$ & $4.89 \mathrm{~b}, \mathrm{~B}$ & $4.78 \mathrm{~B}$ \\
\hline 5 & $5.10 \mathrm{a}, \mathrm{C}$ & $5.28 \mathrm{a}, \mathrm{A}$ & $5.92 \mathrm{~b}, \mathrm{C}$ & $5.43 \mathrm{C}$ & $5.10 \mathrm{a}, \mathrm{C}$ & $5.85 \mathrm{~b}, \mathrm{~B}$ & $6.61 \mathrm{c}, \mathrm{B}$ & $5.85 \mathrm{C}$ & $5.10 \mathrm{a}, \mathrm{C}$ & $5.10 \mathrm{a}, \mathrm{C}$ & $5.05 \mathrm{a}, \mathrm{c}$ & $5.09 \mathrm{C}$ \\
\hline$X$ & $4.73 \mathrm{a}$ & $5.20 \mathrm{~b}$ & $5.61 \mathrm{c}$ & & $4.73 \mathrm{a}$ & $5.63 \mathrm{~b}$ & $6.49 \mathrm{c}$ & & $4.73 \mathrm{ac}$ & $4.75 \mathrm{bc}$ & $4.81 \mathrm{~b}$ & \\
\hline Source of Variation & & $P$ & & & $P$ & & & & $P$ & & & \\
\hline Biochar $(x)$ & & $<0.001$ & & & $<0.001$ & & & & $<0.021$ & & & \\
\hline Compost (y) & & $<0.001$ & & & $<0.001$ & & & & $<0.001$ & & & \\
\hline$x \times y$ & & 0.025 & & & 0.018 & & & & 0.009 & & & \\
\hline
\end{tabular}

Lower case letter indicates significant differences among mean values between columns, while capital letter indicates significant differences among mean values within a column using a two-way ANOVA at a $P<0.05$ level of significance

346 to $14 \mathrm{mg} / \mathrm{kg}$ for $\mathrm{Zn}$ compared to the control (or $93 \%$ and $96 \%$, reductions, respectively; Table 3). Treatment with beef cattle manure biochar was also capable of reducing both bioavailable $\mathrm{Cd}$ and $\mathrm{Zn}$ concentrations, and a greater reduction occurred when this biochar was mixed into the soil with compost (Table 3). On the opposite side, treatment with lodge pole pine biochar was not as effective compared to the other two biochars at reducing bioavailable $\mathrm{Cd}$ and $\mathrm{Zn}$ concentrations (Table 3 ). The reductions in bioavailable $\mathrm{Cd}$ and $\mathrm{Zn}$ based on lodgepole pine biochar alone were not significant as compared to the control $(P<0.27$; Table 3$)$; however, adding compost did improve the level of reduction $(P<0.01$, Table 3$)$. In all treatments, the interaction between biochar and compost was not significant for bioavailable $\mathrm{Cd}$ and $\mathrm{Zn}$ (Table 3). The plots of both bioavailable $\mathrm{Cd}$ and $\mathrm{Zn}$ as a function of soil $\mathrm{pH}$ (Fig. 2a, b) revealed trends that were like those found with water extractable metals (Fig. 1). In these cases, raising soil $\mathrm{pH}$ after biochar additions produced from poultry litter and beef cattle manure reduced bioavailable $\mathrm{Cd}$ and $\mathrm{Zn}$, while lodgepole pine biochar was not as effective at these reductions.

\subsection{Switchgrass growth in treated and untreated soil}

Mean switchgrass above-ground biomass (shoots) and below ground biomass (roots) in the control ( $0 \%$ biochar $/ 0 \%$ compost) was poor (Fig. 3a-c). This showed that native soil conditions are inhospitable for switchgrass growth. In contrast, switchgrass growth was improved after treatment with 5\% compost (no biochar) that resulted in a small, yet significant increase in mean switchgrass shoot masses (Table 4). The influence on switchgrass root growth in soils treated with compost alone was not as clear. These results indicate that compost alone at $5 \%$ application had a significant, but lower impact on improving soil conditions that can positively influence switchgrass shoot and root mean mass results.
Mixed results were observed after mixing in the biochars alone (except lodgepole pine biochar) on mean switchgrass shoot and root masses (Table 4). When compost was added to the biochar treated soils, there were additional significant improvements in switchgrass shoots and root masses (except with poultry litter biochar, Table 4), with similar effects observed by others when utilizing biochar and manures (Lentz and Ippolito 2012). In most cases, the interaction between biochar and compost was significant on switchgrass root and shoot growth. When averaged across biochar and compost treatments, increasing additions of beef cattle manure and poultry litter biochar along with compost addition favored significant increases in switchgrass shoot and root masses with the largest increases occurring at the 5\% application rates (Fig. 3; Table 4). Poorer switchgrass shoots and root mean masses occurred in soil treated with lodgepole pine biochar and compost (Fig. 3; Table 4).

Plotting the switchgrass above-ground biomass (shoots) versus soil $\mathrm{pH}$ (Fig. 4) partially corroborated the individual impacts of biochar and compost on mean shoot and root masses as shown in Table 4. The soil controls treated with $0 \%$ biochar and $0 \%$ or with $2.5 \%$ compost alone had minimal switchgrass shoot growth. In comparison, simply adding a larger amount of compost (5\%) to the soil controls significantly raised soil $\mathrm{pH}$ and resulted in greater shoot mass production. In general, this agrees with statistical results present in Table 4. Similarly, just treating soil with lodgepole pine biochar and 0-2.5\% compost showed low soil $\mathrm{pH}$ responses that kept switchgrass shoot production at a minimum. Mixing in beef cattle manure biochar along with compost greatly increased soil $\mathrm{pH}$ values and facilitated switchgrass shoot masses up to almost $2.5 \mathrm{~g}$ (Fig. 4). Mixing in poultry litter biochar produced mixed impacts on soil $\mathrm{pH}$ and switchgrass shoot mass results. We found that incorporating $5 \%$ poultry litter biochar raised soil $\mathrm{pH}$ values to $>6$, which corresponded to significant reductions in shoot mean masses (Table 4). Ideally, switchgrass growth in soil was 


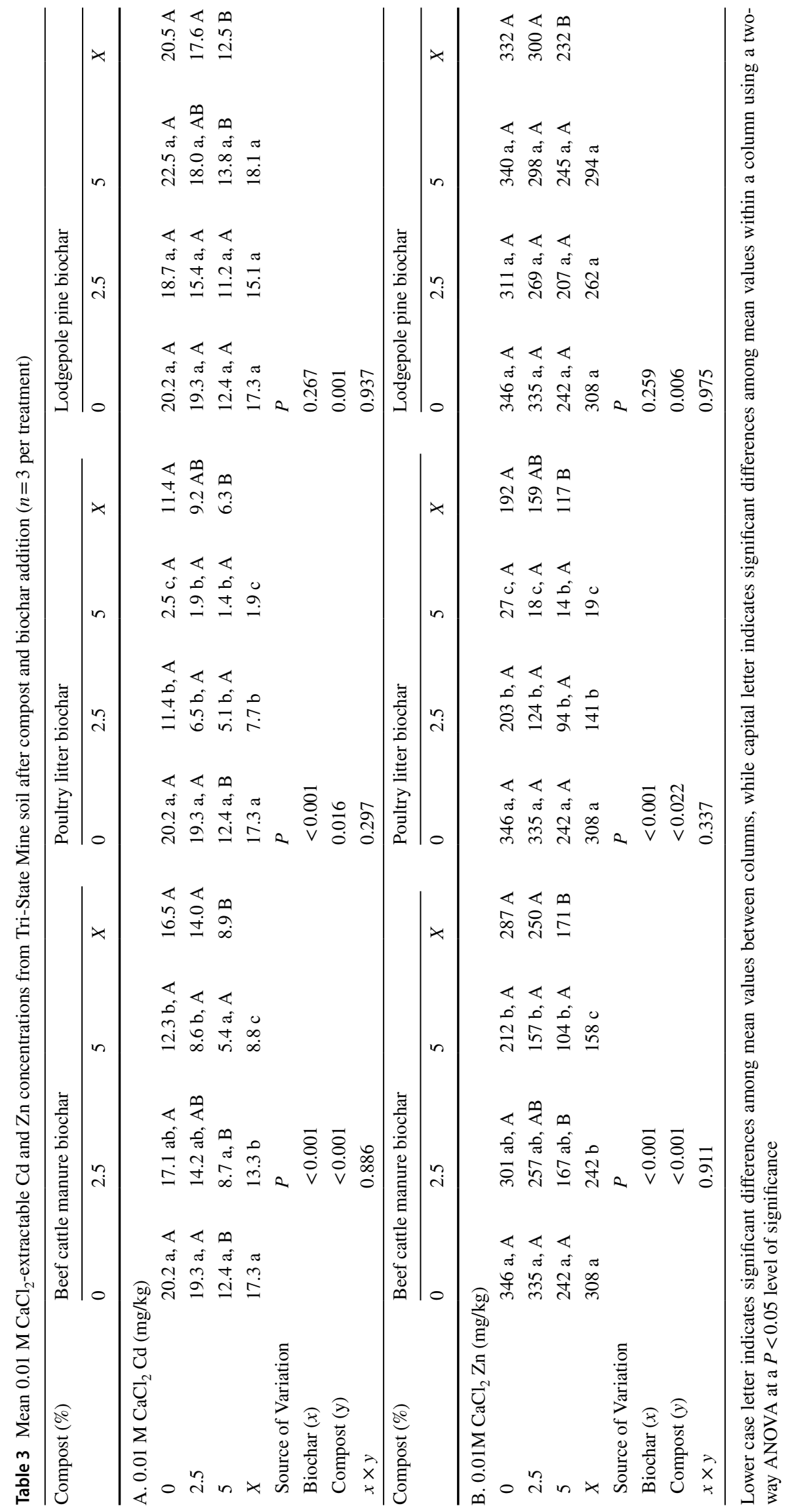



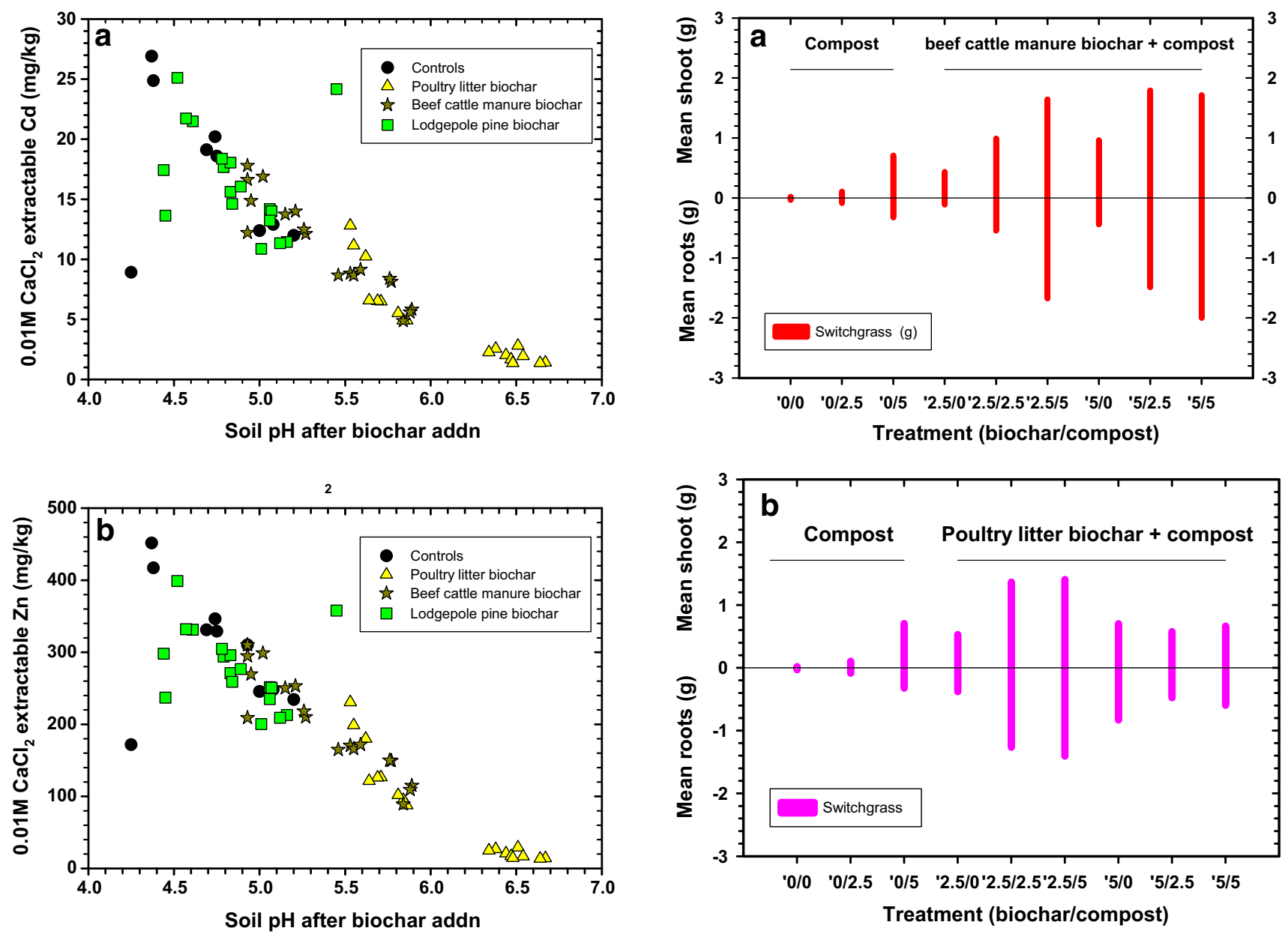

Fig. $20.01 \mathrm{M} \mathrm{CaCl}_{2}$-extractable cadmium $(\mathrm{Cd}, \mathbf{a})$ and zinc $(\mathrm{Zn}, \mathbf{b})$ from compost + biochar-treated Tri-State Mine soil versus their $\mathrm{pH}$ measured at end of study

optimal after treatment with $2.5 \%$ poultry litter biochar and either $2.5 \%$ or $5 \%$ compost treatment. After treatment with $5 \%$ poultry litter biochar, it was possible that switchgrass growth may have been limited by lower concentrations of plant-available $\mathrm{P}$ or other micronutrients due to precipitation at the higher soil $\mathrm{pH}$ values (Fig. 4) and/or by binding of $\mathrm{P}$ to $\mathrm{Al}$ and $\mathrm{Ca}$ in the biochar/compost (Table S2; Bohn et al. 1979). Viewing the clustering of data points between pH 5.3 and 5.9 that represents individual switchgrass aboveground biomass results vs. soil $\mathrm{pH}$ values indicates a suitable $\mathrm{pH}$ range for optimal switchgrass growth in this mine soil (Fig. 4). This finding is within the $\mathrm{pH}$ range of $5-8 \mathrm{pH}$ for switchgrass establishment as reported by Hanson and Johnson (2005).

Verification of improved switchgrass above-ground biomass production was linked to suppression of soil $\mathrm{H}_{2} \mathrm{O}$ extractable and bioavailable $\mathrm{Cd}$ and $\mathrm{Zn}$ concentrations (Figs. 5, 6). For switchgrass above-ground biomass to

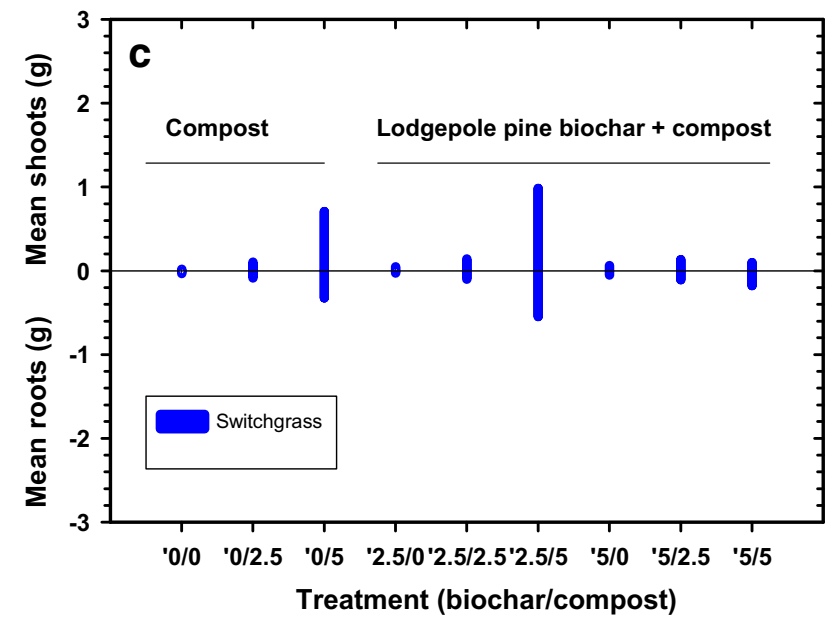

Fig. 3 Mean switchgrass shoot/root masses grown in Tri-State Mine soil treated with compost and beef cattle manure biochar (a), poultry litter biochar (b), and lodgepole pine biochar (c) (treatments expressed as biochar\%/compost \%)

be $>1 \mathrm{~g}$ in this experiment, the biochars and compost needed to reduce $\mathrm{H}_{2} \mathrm{O}$ extractable $\mathrm{Cd}$ and $\mathrm{Zn}$ concentrations to $<1.5$ and $50 \mathrm{mg} / \mathrm{kg}$, respectively (Fig. 5). Maximum switchgrass 


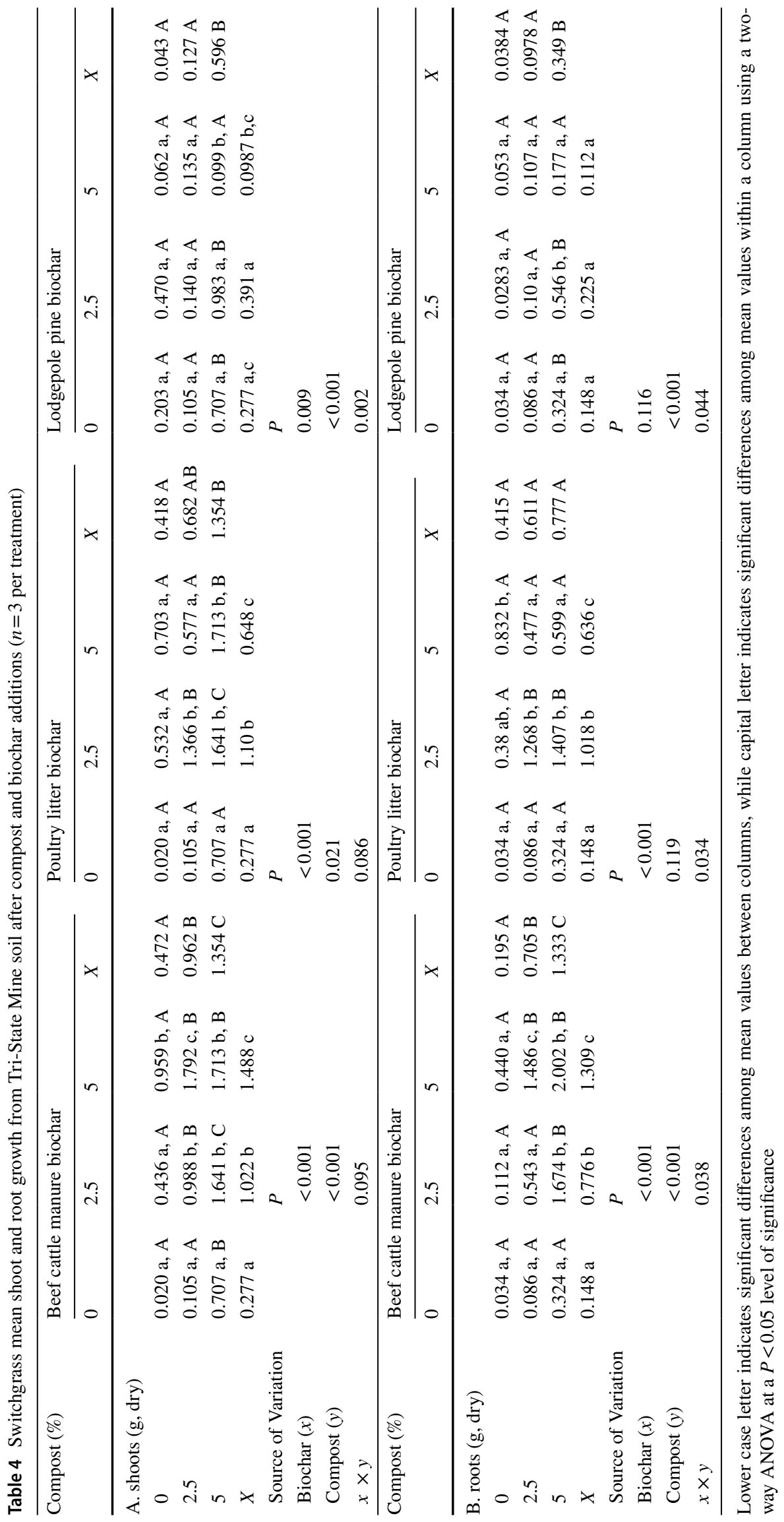




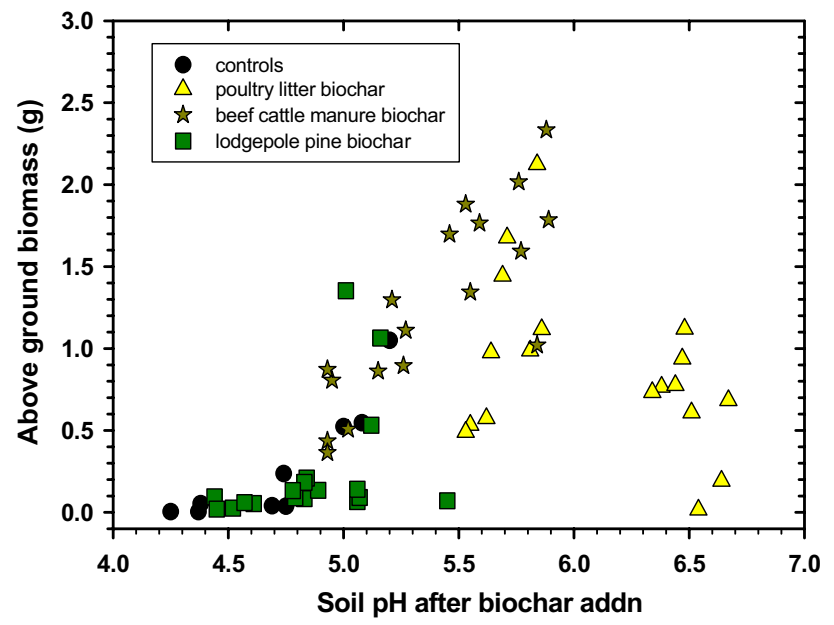

Fig. 4 Switchgrass above-ground biomass versus Tri-State Mine soil $\mathrm{pH}$ measured after compost and biochar additions

growth was possible (or $>1.5 \mathrm{~g}$ ) when the $\mathrm{H}_{2} \mathrm{O}$ extractable $\mathrm{Cd}$ and $\mathrm{Zn}$ concentrations were further reduced to $<1.0$ and $40 \mathrm{mg} / \mathrm{kg}$, respectively. The above-ground switchgrass biomass versus the $0.01 \mathrm{M} \mathrm{CaCl}_{2}$ extractable $\mathrm{Cd}$ and $\mathrm{Zn}$ concentration results followed a similar trend. Here, $\mathrm{Cd}$ and $\mathrm{Zn}$ concentrations should be reduced to $<10$ and $150 \mathrm{mg} / \mathrm{kg}$, respectively, for maximum switchgrass biomass production $(>1.5 \mathrm{~g})$. Treatment of this soil with poultry litter biochar and beef cattle manure biochar and compost at certain applications will promote better switchgrass growth, meanwhile treatment with lodgepole pine biochar and compost produced poorer results. The lesser switchgrass above-ground biomass results are a consequence of the lodgepole pine biochar lacking the capability to reduce water and bioavailable $\mathrm{Cd}$ and $\mathrm{Zn}$ concentrations (Figs. 5, 6).

\section{4 $\mathrm{Cd}$ and $\mathrm{Zn}$ concentrations measured in switchgrass shoots and roots}

Cadmium is not an essential plant nutrient but is taken up by plants nonetheless (Kirkham 2006; Hasan et al. 2009). Plants, in general, can tolerate certain amounts of $\mathrm{Cd}$, but $\mathrm{Cd}$ interferes with many physiological functions and can also induce phytotoxicity (Hasan et al. 2009; Khan et al. 2017). Reed et al (2002) reported that switchgrass (Alamo variety) grown in soil spiked with $200 \mathrm{mg} / \mathrm{kg}$ Cd decreased biomass accumulation by $95 \%$ with Cd concentrations measured at $900 \mathrm{mg} / \mathrm{kg}$ in root tissue while up to $100 \mathrm{mg} / \mathrm{kg} \mathrm{Cd}$ was measured in switchgrass leaf tissue. In their study, the Cd concentrations in switchgrass roots and stems varied
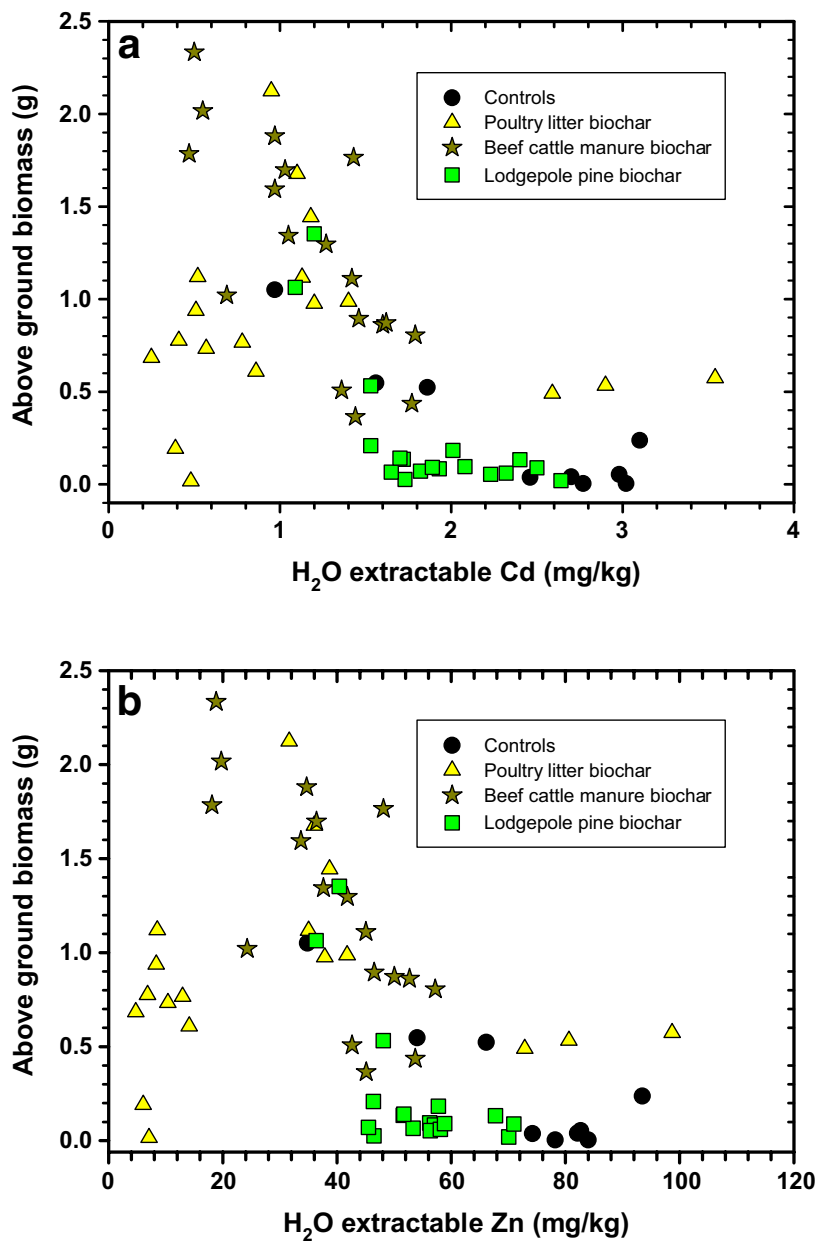

Fig. 5 Water-extractable cadmium $(\mathrm{Cd}$, a) and zinc $(\mathrm{Zn}, \mathbf{b})$ from compost+biochar-treated Tri-State Mine soil versus switchgrass above-ground biomass measured at end of study

considerably with soil $\mathrm{pH}$ with greater plant concentrations measured when the experiments were conducted at low soil $\mathrm{pH}$ (4.01). Opposite to $\mathrm{Cd}, \mathrm{Zn}$ is a plant micronutrient that is important for cellular enzymatic functions, protein production, and membrane integrity (Marschner 1995). When grown in soils with high $\mathrm{Zn}$ contents, plants can store more $\mathrm{Zn}$ in their roots than in the above-ground biomass, i.e., it is not readily translocated (Godbold et al. 1984). If grown in soils with excessive $\mathrm{Zn}$ levels, however, plants growth is inhibited, due to soil $\mathrm{Zn}$ toxicity causing root apical meristem necrosis, and eventually plant death follows. Zn toxicity levels in plants vary greatly, but Marschner (1995) reported that critical toxicity levels in plant leaves occur between 100 to more than $300 \mathrm{mg} / \mathrm{kg}$. 

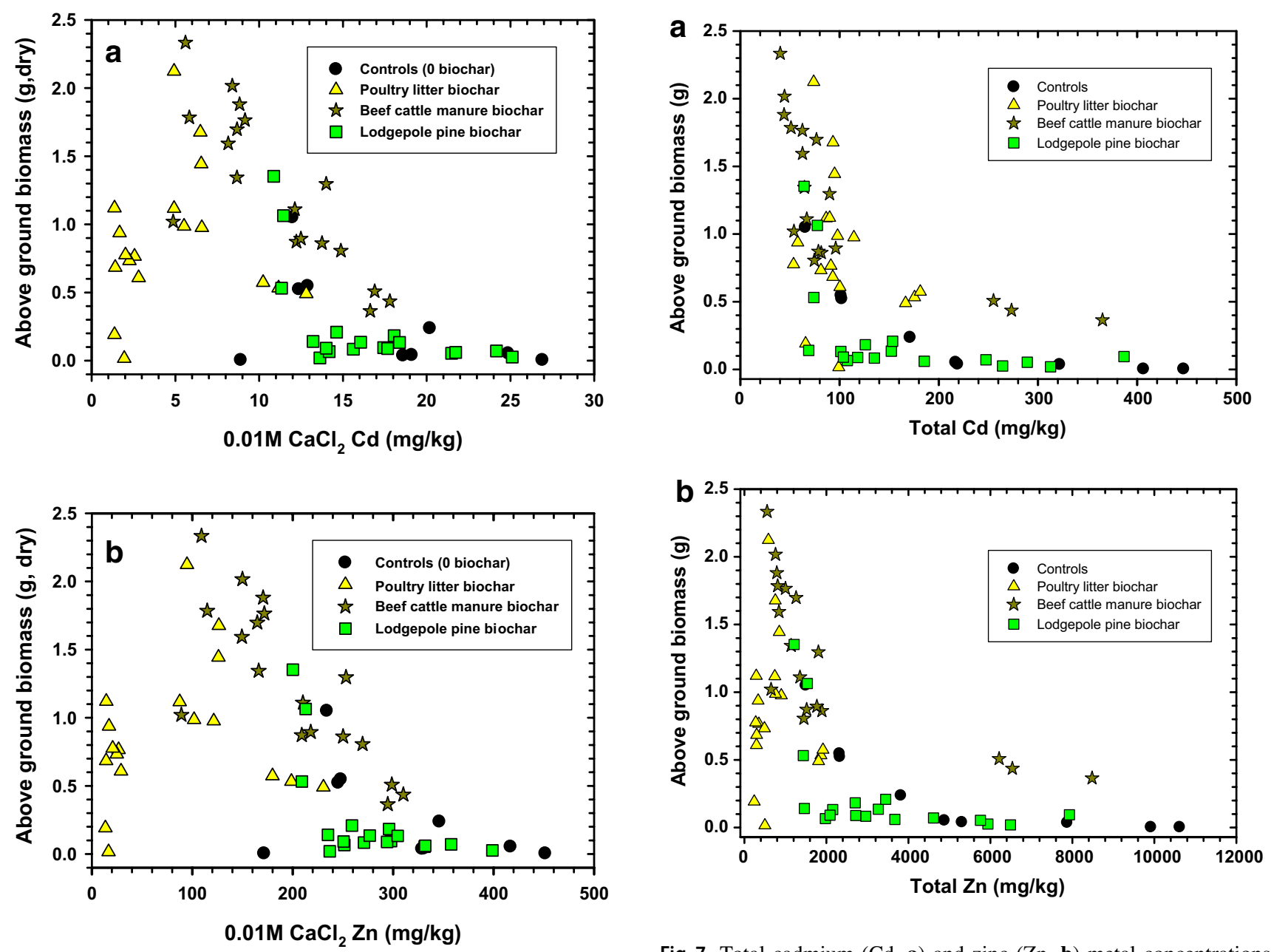

Fig. $60.01 \mathrm{M} \mathrm{CaCl}_{2}$ extractable cadmium $(\mathrm{Cd}, \mathbf{a})$ and zinc $(\mathrm{Zn}, \mathbf{b})$ from compost + biochar-treated Tri-State Mine soil versus switchgrass above-ground biomass measured at end of study

Figure 7 shows the overall relationship between total $\mathrm{Cd}$ (a) and total $\mathrm{Zn}$ (b) measured in switchgrass above-ground biomass as a function of biochar/compost treatment. The lowest total $\mathrm{Cd}$ measured $(<100 \mathrm{mg} / \mathrm{kg})$ in switchgrass above-ground biomass occurred in plants grown in soil treated with biochar produced from poultry litter and beef cattle manure plus compost. Results presented in Table 5 support the significant decline in mean total Cd concentrations in switchgrass shoots after treatment with these two biochars. In fact, total Cd concentrations measured in switchgrass shoots were reduced by $74 \%$ and $64 \%$, respectively, after treatment with 5\% biochar produced from poultry litter and beef cattle manure feedstocks and 5\% compost (Table 5). This agrees with previous results that showed reduced $\mathrm{H}_{2} \mathrm{O}$ and bioavailable-Cd concentrations as in Figs. 1 and 2. This trend is linked to an increase in soil

Fig. 7 Total cadmium $(\mathrm{Cd}, \mathbf{a})$ and zinc $(\mathrm{Zn}, \mathrm{b})$ metal concentrations measured in switchgrass above-ground biomass at end of study

$\mathrm{pH}$ following poultry litter and beef cattle manure biochar plus compost that reduces Cd solubility (Reed et al. 2002; Kirkham 2006). Biochar produced from lodgepole pine \pm compost presented an inferior choice to suppress $\mathrm{Cd}$ assimilation because between 60 and $385 \mathrm{mg} / \mathrm{kg}$ were measured in switchgrass above-ground biomass (Fig. 7a). As shown in Table 5, there were some minor decreases in mean total $\mathrm{Cd}$ measured in switchgrass shoots, but the reduction was only about $35 \%$ when treated with 5\% lodgepole biochar plus $5 \%$ compost as compared to the control at $0 \%$ biochar $/ 0 \%$ compost (Table 5).

Total $\mathrm{Zn}$ concentrations in switchgrass above-ground biomass (Fig. 7b) followed a similar trend as observed with total $\mathrm{Cd}$-biochars that caused greater increases in soil $\mathrm{pH}$ were more successful at reducing total $\mathrm{Zn}$ uptake. Mean total $\mathrm{Zn}$ concentrations were reduced between $81 \%$ and $94 \%$, respectively, after soils were treated with biochar produced from beef cattle manure and poultry litter feedstocks plus $5 \%$ compost as compared to the control without 


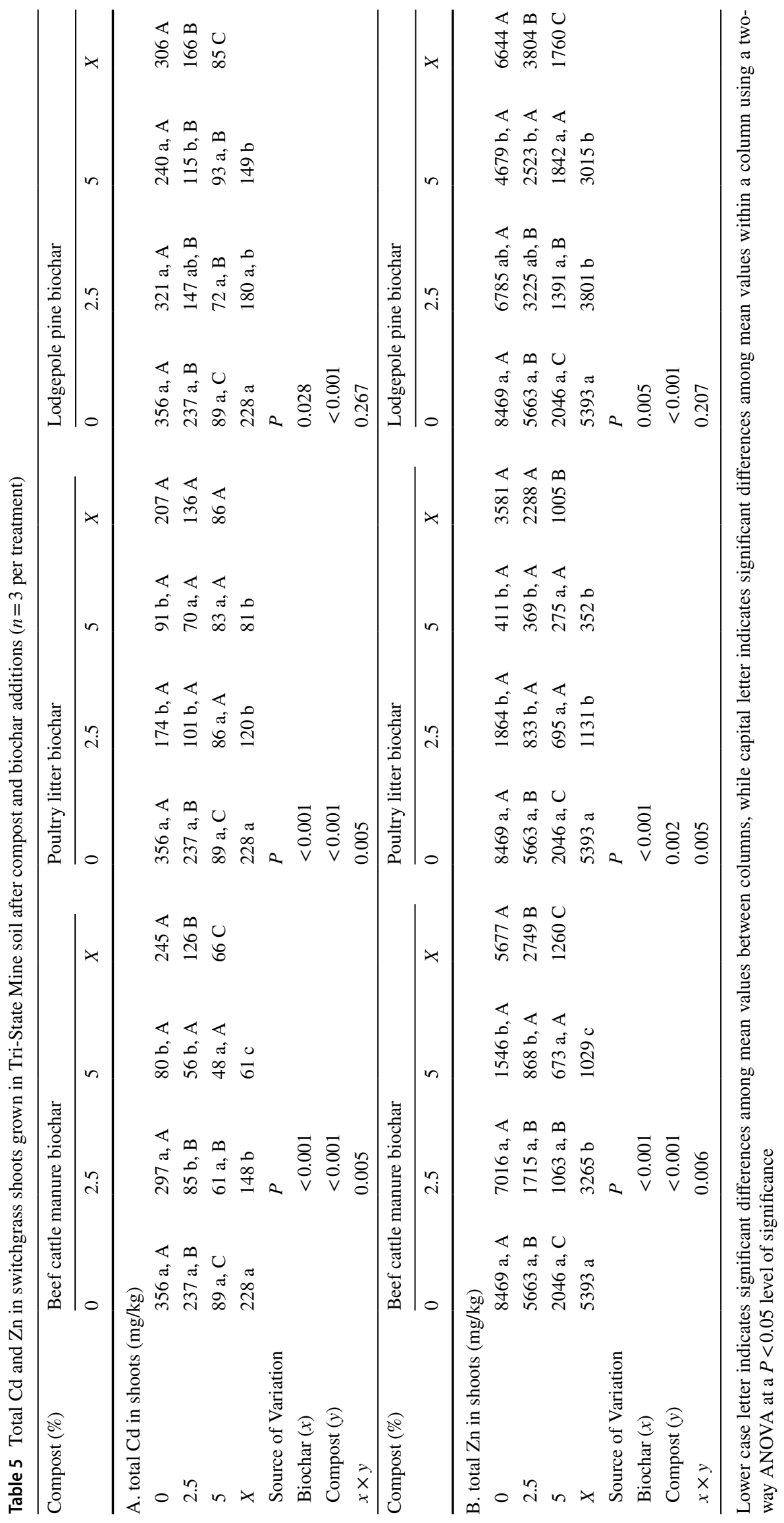



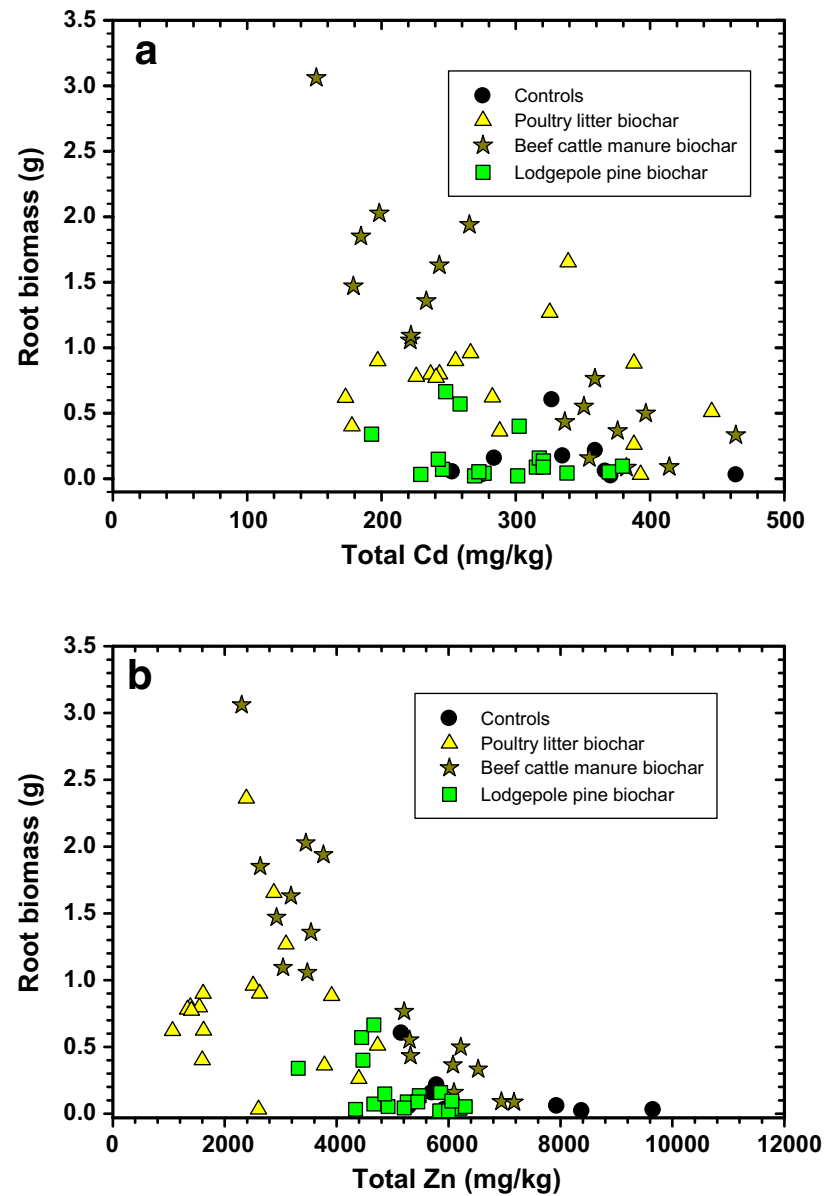

Fig. 8 Total cadmium $(\mathrm{Cd}, \mathbf{a})$ and zinc $(\mathrm{Zn}, \mathbf{b})$ metal concentrations measured in switchgrass roots at end of study

any amendments (Table 5). Less total $\mathrm{Zn}$ was measured in switchgrass above-ground biomass after soils were treated with biochars produced from poultry litter and beef cattle manure feedstocks compared to lodgepole pine biochar ( \pm compost). Treatment of soil with $2.5 \%$ lodgepole pine biochar plus 5\% compost produced significant reductions in total $\mathrm{Zn}$ in shoots of $30 \%$ as compared to the mean treated with only $5 \%$ compost. Compost added alone to the soil was itself an effective amendment to reduce total $\mathrm{Cd}$ and $\mathrm{Zn}$ in shoots. Application of 5\% compost alone was able to significantly reduce total $\mathrm{Cd}$ and $\mathrm{Zn}$ concentrations by about $75 \%$ in shoots compared to the untreated control (Table 5). The benefit of switchgrass containing lower total $\mathrm{Cd}$ and $\mathrm{Zn}$ concentrations is highlighted in Fig. 7a, b, which shows greater switchgrass above-ground biomass production after reduced uptake of these two metals. Antidotally, if the TriState Mining District site were to be reclaimed using the above-mentioned techniques, plants grown on site may contain lower $\mathrm{Cd}$ and $\mathrm{Zn}$ concentrations and thus be less of an issue to grazing wildlife in terms of food chain conclusions.

Total $\mathrm{Cd}$ and $\mathrm{Zn}$ measured in switchgrass roots is shown in Fig. 8a, b. Total Cd in roots as a function of biochar treatment shows a complex pattern with some minor differentiation between treatments. Soil treated with biochar produced from beef cattle manure and poultry litter feedstocks cause significant reductions in total $\mathrm{Cd}$ and $\mathrm{Zn}$ contents in roots, but the significance of the reduction was dependent on quantities of biochar and compost applied (Table 6). In soils treated with $5 \%$ beef cattle manure biochar and poultry litter biochar and 5\% compost, the largest reductions in mean total $\mathrm{Cd}$ and $\mathrm{Zn}$ concentrations measured in roots occurred. Soils treated with lodgepole pine biochar and compost showed significant reductions at application of $2.5 \%$ on total $\mathrm{Zn}$ in roots, but the treatments had no significant impact on means of total Cd in switchgrass roots (Table 6). Obviously, treatment of this mine soil with lodgepole pine biochar and compost would not be the most efficient biochar available for reduced metal uptake by switchgrass.

\section{Conclusions}

Biochar and compost amendments have emerged as potential remediation agents for sequestering heavy metals in mine spoils or in mine-impacted soils. This study evaluated the three biochar types produced from poultry litter, beef cattle manure, and lodgepole pine feedstocks, mixed into metalcontaminated soils with or without compost, on their ability to sequester $\mathrm{Cd}$ and $\mathrm{Zn}$ to levels that would allow switchgrass growth in a mine-impacted soil. Key findings were that the biochars differed greatly in their ability to reduce $\mathrm{H}_{2} \mathrm{O}$ extractable and bioavailable $\mathrm{Cd}$ and $\mathrm{Zn}$ - poultry litter and beef cattle manure biochar were more effective at reducing extractable $\mathrm{Cd}$ and $\mathrm{Zn}$ concentrations than lodgepole pine biochar. This condition was related to the ability of these two biochars to raise soil $\mathrm{pH}$ to $>5$ which reduced the solubility of $\mathrm{Cd}$ and $\mathrm{Zn}$ and hence lowered their extractable concentrations. The greatest switchgrass and above-ground biomass and root production occurred in soils treated with $2.5 \%$ and $5 \%$ biochar from poultry litter and beef cattle manure plus $5 \%$ compost. In general, compost by itself was able to reduce soil-extractable $\mathrm{Cd}$ and $\mathrm{Zn}$ concentrations and total $\mathrm{Cd}$ and $\mathrm{Zn}$ in switchgrass shoots particularly at the 5\% application rate. This study corroborates the finding that biochars should be carefully designed for their ability to modify soil conditions (i.e., increase $\mathrm{pH}$, etc.) to greatly reduce bioavailable $\mathrm{Cd}$ and $\mathrm{Zn}$ concentrations in mine-impacted soils. If 


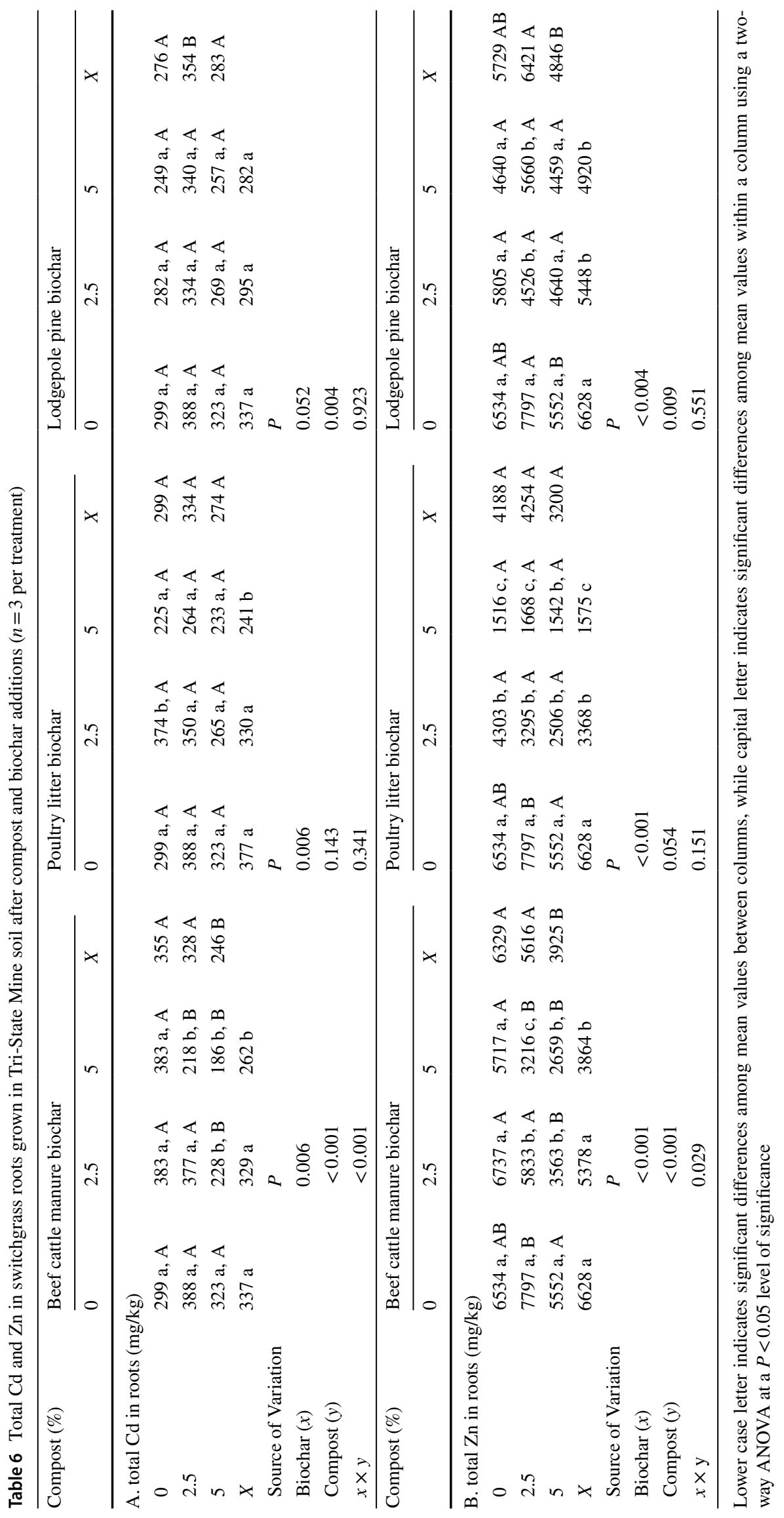


adopted, this paradigm can result in an optimized selection and application of the most efficient biochar in a mine spoil remediation plan.

Acknowledgements Gratitude is expressed to the staff of the ARS, the US EPA locations, and team at the Webb City, MO water treatment facility for their work and diligence with sample collection, preparation and analyses. This work was made possible through an Interagency Agreement between the United States Department of AgricultureAgricultural Research Service (60-6657-1-204) and the US EPA (DE12-92342301-2). It has been subject to peer review by scientists of the United States Department of Agriculture-Agricultural Research Service (USDA-ARS) at multiple locations and by the National Health and Environment Effects Research Laboratory's Western Ecology Division and approved for journal submission. Approval does not signify that the contents reflect the views of the USDA-ARS or the US EPA, nor does mention of trade names or commercial products constitute endorsement or recommendation for their use. USDA is an equal opportunity provider and employer.

Open Access This article is distributed under the terms of the Creative Commons Attribution 4.0 International License (http://creativeco mmons.org/licenses/by/4.0/), which permits unrestricted use, distribution, and reproduction in any medium, provided you give appropriate credit to the original author(s) and the source, provide a link to the Creative Commons license, and indicate if changes were made.

\section{References}

Abbot DE, Essington ME, Mullen MD, Ammons JT (2001) Flu ash and lime stabilized biosolids mixtures in mine spoil reclamation: simulated weathering. J Environ Qual 30:608-616

Ahmad M, Rajapaksha AU, Lim JE, Zhang M, Bolan N, Mohan D, Vithanage M, Lee SS, Ok YS (2014) Biochar as a sorbent for contaminant management in soil and water: a review. Chemosphere 99:19-33

Ahmad M, Usman ARA, Al-Faraj AS, Ahmad M, Sallam A, Al-Wabel MI (2018) Phosphorus-loaded biochar changes soil heavy metal availability and uptake potential of maize (Zea mays L.) plants. Chemosphere 194:327-339

Anawar HM, Akter F, Solaiman ZM, Strezova V (2015) Biochar: a emerging panacea for remediation of soil contaminants from mining, industry, and sewage practices. Pedosphere 25:654-665

Anderson NM, Bergman RD, Page-Dumroese DE (2016) A supply chain approach to biochar systems. In: Bruckman VJ, Varol EA, Uzun BB, Liu J (eds)Biochar: a regional supply chain approach in view of mitigating climate change. Cambridge Press, London, pp 25-26

ASTM (2006) Petroleum products, lubricants, and fossil fuels: gaseous fuels, coal, and coke. ASTM International, Conshohocken

Beesley L, Marmiroli M (2011) The immobilization and retention of soluble arsenic, cadmium and zinc by biochar. Environ Pollut 159:474-480

Boateng AA, Garcia-Perez M, Mašek O, Brown R, del Campo B (2015) Biochar production technology. In: Lehmann J, Joseph SJ (eds) Biochar for environmental management: science, technology, and implementation, 2nd edn. Earthscan, Rutledge, pp 63-87

Bohn H, McNeal B, O'Connor G (1979) Soil chemistry. Wiley, New York, pp 1-329

Bradford GR, Page AL, Lund LJ, Olmstead W (1975) Trace element concentrations of sewage treatment plant effluents and sludges: their interaction with soil and uptake by plants. J Environ Qual 4:123-127

Brockhoff SR, Christians NE, Killorn RJ, Horton R, Davis DD (2010) Physical and mineral-nutrition properties of sand-based turfgrass root zones amended with biochar. Agron J 102:1627-1631

Brown SL, Henry CL, Chaney R, Compton H, Devolder PS (2003a) Using municipal biosolids in combination with other residuals to restore metal-contaminated mining areas. Plant Soil 249:203-215

Brown RW, Amacher MC, Mueggler WF, Kotuby-Amacher J (2003b) Reestablishing natural succession on acidic mine spoils at high elevation: long-term ecological restoration. USDA-Forest Service, research paper RMRS-RP-41, pp 1-49

Cantrell KB, Hunt PG, Uchimiya M, Novak JM, Ro KS (2012) Impact of pyrolysis temperature and manure source on physicochemical characteristics of biochar. Bioresour Technol 107:419-428

Cardoso EJ, Vasconcellos RL, Bini D, Miyauchi MY, dos Santos CA, Alves PR, de Paula AM, Nakatani AS, de Moraes Perira J, Nogueira MA (2013) Soil Health: Looking for suitable indicators. What should be considered to assess the effects of use and management on soil health? Sci Agric 70:274-289

Cui H, Zhou J, Zhao Q, Si Y, Mao J, Fang G, Liang J (2013) Fractions of $\mathrm{Cu}, \mathrm{Cd}$, and enzyme activities in a contaminated soil as affected by application of micro-and nanohydroxyapatite. J Soils Sediments 13:742-752

Ducey TF, Ippolito JA, Cantrell KB, Novak JM, Lentz RD (2013) Addition of activated switchgrass biochar to an aridic subsoil increases microbial nitrogen cycling gene abundances. Appl Soil Ecol 55:65-72

Dudka S, Adriano DC (1997) Environmental impacts of metal ore mining and processing: a review. J Environ Qual 26:590-602

Ehsan M, Barakat MA, Husein DZ, Ismail SM (2014) Immobilization of $\mathrm{Ni}$ and $\mathrm{Cd}$ in soil by biochar derived from unfertilized dates. Water Air Soil Pollut 225:2123-2133

Enders A, Hanley K, Whitman T, Joseph S, Lehmann J (2012) Characterization of biochars to evaluate recalcitrance and agronomic performance. Bioresour Technol 114:644-653

EPA (2018) Environmental Protection Agency Oronogo-Duenweg Mining Belt Joplin, MO. https://cumulis.epa.gov/supercpad/ siteprofiles/index.cfm?fuseaction $=$ second.redevelop\&id $=07012$ 90. Accessed 8 Nov 2018

Fellet G, Marchiol L, Delle Vedove G, Peressotti A (2011) Application of biochar on mine tailings: effects and perspectives for land reclamation. Chemosphere 83:1262-1267

Figueroa F, Castro-Larragoitia J, Aragón A, García-Meza JV (2010) Grass cover density and metal speciation in profiles of a tailingspile from mining zones in Zacatecas, North-Central Mexico. Environ Earth Sci 60:395-407

Gibson AM (1972) Wilderness Bonanza: the Tri-State Mining District of Mossouri, Kansas, and Oklahoma. Univ. Oklahoma Press, Norman (ISBN: 13:9780806109909)

Godbold DL, Horst WJ, Collins JC, Thurman DA, Marschner H (1984) Accumulation of zinc and organic acids in roots of zinc tolerant and non-tolerant ecotypes of Deschampsia caespitosa. J Plant Physiol 116:59-69

Gorman JM, Sencindiver JC, Horvath DJ, Singhand RN, Keefer RF (2000) Erodibility of fly ash used as a topsoil substitute in mineland reclamation. J Environ Qual 29:805-811

Gunamantha IM, Widana GAB (2018) characterization the potential of biochar from cow and pig manure for geoecology application. IOP Conf Ser Earth Environ Sci 131:012055

Guo M, Qiu G, Song W (2009) Poultry litter-based activated carbon for removing heavy metal ions in water. Waste Manag 30:308-315

Guo M, He Z, Uchimiya SM (2015) Introduction to biochar as an agricultural and environmental amendment. In: Guo M, He Z, Uchimiya M (eds) Agricultural and environmental application of 
biochar: advances and barriers. Soil Science Society of America Special Publications 63, pp 1-14

Haering KC, Daniels WL, Feagly SE (2000) Reclaiming mined lands with biosolids, manures, and papermill sludges. In: Barnhisel $\mathrm{R}$ (ed) Reclamation of drastically disturbed lands. SSSA, Inc, Madison, pp 615-644

Hanauer T, Jung S, Felix-Henningsen P, Schnell S, Steffens D (2012) Suitability of inorganic and organic amendments for in situ immobilization of $\mathrm{Cd}, \mathrm{Cu}$, and $\mathrm{Zn}$ in a strongly contaminated Kastanozem on the Mashavera valley, SE Georgia. I. Effect of amendments on metal mobility and microbial ACTIVITY in soil. J Plant Nutr Soil Sci 175:708-720

Hanson JD, Johnson HA (2005) Germination of switchgrass under various temperature and $\mathrm{pH}$ regimes. Seed Technol 27:203-210

Hasan SA, Fariduddin Q, Ali B, Hayat S, Ahmad A (2009) Cadmium: toxicity and tolerance in plants. J Environ Biol 30:165-174

Hensley DL, Carpenter PL (1984) Effect of lime additions to acid stripmine spoil on survival, growth and nitrogen fixation (acetylene reduction) of several woody legumes and actinomycete-nodulated species. Plant Soil 79:353-367

Hu XF, Jiang Y, Shu Y, Hu X, Liu L, Luo F (2014) Effects of mining wastewater discharges on heavy metal pollution and soil enzyme activity of the paddy fields. J Geochem Explor 147:139-150

Huang CL, Schulte EE (1985) Digestion of plant tissue for analysis by ICP emission spectroscopy. Commun Soil Sci Plant Anal 16:943-958

Ippolito JA, Spokas KA, Novak JM, Lentz RD, Cantrell KB (2015) Biochar elemental composition and factors influencing nutrient retention. In: Lehmann J, Joseph SJ (eds) Biochar for environmental management: science, technology, and implementation, 2nd edn. Earthscan, Rutledge, pp 139-164

Ippolito JA, Berry CM, Strawn DG, Novak JM, Levine J, Harley A (2017) Biochars reduce mineland soil bioavailable metals. J Environ Qual 46:411-419

Jian S, Baruah BP, Khare P (2014) Kinetic leaching of high sulpher mine rejects amended with biochar: Buffering implication. Ecol Eng 71:703-709

Johnson AW, Gutiérrez M, Gouzie D, McAiley LR (2016) State of remediation and metal toxicity in the Tri-State Mining District, USA. Chemosphere 144:1132-1141

Kabata-Pendias A (2001) Trace elements in soils and plants, 3rd edn. CRC Press, Boca Raton

Kelly CN, Peltz CD, Stanton M, Rutherford DW, Rostad CE (2014) Biochar application to hardrock mine tailings: Soil Quality, microbial activity, and toxic element sorption. Appl Geochem 43:35-48

Khan MA, Khan S, Khan A, Alam M (2017) Soil contamination with cadmium, consequences and remediation using organic amendments. Sci Total Environ 601-602:1591-1605

Kim RY, Yoon JK, Kim TS, Yang JE, Owens G, Kim KR (2015) Bioavailability of heavy metals in soils: definitions and practical implementation - a critical review. Environ Geochem Health 37:1041-1061

Kirkham MB (2006) Cadmium in plants on polluted soils: effects of soil factors, hyperaccumulation, and amendments. Geoderma 137:19-32

Kumar A, Tsechansky L, Lew B, Raveh E, Frenkel O, Graber ER (2018) Biochar alleviates phytotoxicity in Ficus elastics in Zncontaminated soil. Sci Total Environ 618:188-198

Laird DA, Brown RC, Amonette JE, Lehmann J (2009) review of the pyrolysis platform for coproducing bio-oil and biochar. Biofuels Bioprod Bioref 3:547-562

Lentz RD, Ippolito JA (2012) Biochar and manure affects calcareous soil and corn silage nutrients concentrations and uptake. J Environ Qual 41:1033-1043

Li RS, Daniels WL (1997) Reclamation of coal refuse with papermill sludge amendment. In: Brandt JE (ed) Proceedings national meeting American Society Surficial Mining and Reclamation, Austin TX, ASSMR, Princeton, WV, USA, 10-15 May, pp 277-290

Liu WJ, Jiang H, Yu HQ (2015) Development of biochar-based functional materials: toward a sustainable platform carbon material. Chem Rev 115:12251-12285

Maiti D, Maiti SK (2014) Ecorestoration of waste dump by the establishment of grass-legume cover. Int J Sci Technol Res 3:37-41

Marschner H (1995) Mineral nutrition of higher plants, 2nd edn. Academic Press, San Diego, pp 1-889

Nie C, Yang X, Niazi NK, Xu X, Wen Y, Rinklebe J, Ok YS, Hu S, Wang H (2018) Impact of sugarcane-bagasse-derived biochar on heavy metal availability and microbial activity: a field study. Chemosphere 200:274-282

Norland MR (1993) Reclamation of abandoned Tri-State Mining District lead-zinc chat tailing. In: Proceedings of the Association of Abandoned Mine Land Programs, Jackson, WY, USA, 13-15 Sept 1993, pp 1-33

Novak JM, Busscher WJ, Laird DL, Ahmedna M, Watts DW, Niandou MAS (2009) Impact of biochar amendment on fertility of a southeastern Coastal Plain soil. Soil Sci 174:105-112

Novak JM, Cantrell KB, Watts DW (2013) Compositional and thermal evaluation of lignocellulosic and poultry litter chars via high and low temperature pyrolysis. Bioenergy Res 6:114-130

Novak JM, Cantrell KB, Watts DW, Busscher WJ, Johnson MG (2014) Designing relevant biochar as soil amendments using lingo-cellulosic-based and manure-based feedstocks. J Soil Sediments 14:330-343

Novak JM, Ippolito JA, Ducey TF, Watts DW, Spokas KA, Trippe KM, Sigua GC, Johnson MG (2018) Remediation of an acidic mine spoil: Miscanthus biochar and lime amendment affects metal availability, plant growth, and soil enzyme activity. Chemosphere 205:709-718

O'Connor D, Peng T, Zhang J, Tsang DCW, Alessi DS, Shen Z, Bolan NS, Hou D (2018) Biochar application for the remediation of heavy metal polluted land: a review of in situ field trials. Sci Total Environ 619-620:815-826

Phillips CL, Trippe KM, Whittaker G, Griffith SM, Johnson MG, Banowetz GM (2016) Gasified grass and wood biochars facilitate plant establishment in acid mine soils. J Environ Qual 45:1013-1020

Reed RL, Sanderson MA, Allen VG, Zartman RE (2002) Cadmium application and $\mathrm{pH}$ effects on growth and cadmium accumulation in switchgrass. Commun Soil Sci Plant Anal 33:1187-1203

Riley RG, Zachara JM, Wobber FJ (1992) Chemical contaminants on DOE lands and selections of contaminated mixtures for subsurface science research. US-DOE, Energy Resource Subsurface Science Program, Washington, DC

Rizwan M, Ali S, Qayyum MF, Ibrahim M, Zia-ur-Rehman M, Abbas T, Ok YS (2016) Mechanism of biochar-mediated alleviation of toxicity of trace elements in plants: a critical review. Environ Sci Pollut Res 23:2230-2248

Robertson SJ, Rutherford MR, López-Gutiérrez JC, Massicotte HB (2012) Biochar enhances seedling growth and alters root symbioses and properties of sub-boreal forest soils. Can J Soil Sci 92:329-340

Schreurs E, Voets T, Thewys T (2011) GIS-based assessment of the biomass potential from phytoremediation of contaminated agricultural land in the Campine region in Belgium. Biomass Bioenergy 35:4469-4480

Sizmur T, Quilliam R, Puga AP, Moreno-Jiménez E, Beesley L, Gomes-Eyles JL (2015) Application of biochars for soil remediation. In: Guo M, He Z, Uchimiya M (eds) Agricultural and environmental application of biochar: advances and barriers. Soil Science Society of America Special Publications 63, pp 295-324 
Spokas KA, Cantrell KB, Novak JM, Archer DW, Ippolito JA, Collins HP, Boateng AA, Lima IM, Lamb MC, McAloon AJ, Lentz RD, Nichols KA (2012) Biochar: a synthesis of its agronomic impact beyond carbon sequestration. J Environ Qual 41:973-989

Srivastava A, Chhonkur PK (2000) Amelioration of coal mine spoils through fly ash applications as liming materials. J Sci Ind Res 59:309-313

Soil Survey of Jasper County, Missouri (2002) https://www.nrcs. usda.gov/Internet/FSE_manuscripts/Missouri/MOO97)/Jaspe r_MO.pdf. Accessed 8 Nov 2018

Wang Y, Lin Y, Chiu PC, Imhoff PT, Guo M (2015) Phosphorus releases behaviors of poultry litter biochar as a soil amendment. Sci Total Environ 15:512-513

Wang S, Xu Y, Norbu N, Wang Z (2018) Remediation of biochar on heavy metal polluted soils. IOP Conf Ser: Earth Environ Sci 108:042113

Waqas M, Khan S, Qing H, Reid BJ, Chao C (2014) The effects of sewage sludge and sewage sludge biochar on PAHs and potentially toxic element bioaccumulation in Cucumis sativa L. Chemosphere 105:53-61

Wauana RA, Okieimen FE (2011) Heavy metals in contaminated soils: a review of sources, chemistry, risks and best available strategies for remediation. ISRN. https://doi.org/10.5402/2011/40264 7 (article ID 402647)

Xie T, Reddy KR, Wang C, Yargicoglu E, Spokas K (2015) Characteristics and application of biochar for environmental remediation: a review. Crit Rev Environ Sci Tech 45:939-969

Yuan JH, Xu RK (2011) The amelioration effects of low temperature biochar generated from nine crop residues on acidic Ultisols. Soil Use Manag 27:110-115

Zheng H, Wang Z, Deng X, Luo J, Novak J, Herbert S, Xing B (2013) Characteristics and nutrient values of biochars produced from giant reed at different temperatures. Bioresour Technol 130:463-471 